\title{
Evaluation of investor attractiveness of power-generating companies: special reference to the development risks of the electric power industry
}

\author{
A. Domnikov, G. Chebotareva \& M. Khodorovsky \\ Banking chair, Ural Federal University after the first President of Russia \\ B. N. Yeltsin, Russia
}

\begin{abstract}
The paper presents the author's methodical approach to the investor attractiveness evaluation of power-generating companies on the basis of risks development decomposition, which can calculate the value of risks in the financing of electricity capital projects.

Keywords: electricity, investor attractiveness, electricity system, powergenerating company, power-generating object, risks of development, the cost of development risks.
\end{abstract}

\section{Introduction}

Electricity is one of the most important branches of fuel and energy complex, providing a multilateral and profound impact on social and economic development and the environment. This is due to the high importance of its manufactured products - electricity energy and the large proportion of the heat. It is not the functioning of the national economic complex and the livelihoods of the population [1]. Therefore, the solving of industry problems (regarding quality, reliability and sustainable economic power supply) requires the periodical financing of the economy. However, capital project financing involves a comprehensive complex assessment of its investor attractiveness, including the potential costs from the identified risks scale $[2,3]$. 


\section{Electricity development risks}

The graphic-analytical methodical approach, that is present in this paper, calculates the development risks at the different levels of the electricity system. The first level is the power generating company (PGC), which directs and regulates the realization of all the company projects and is therefore responsible for the financial needs and for providing all of the production. The PGC composition includes different types of electricity stations: heat stations, condensation stations and hydropower stations. These PGC elements are the second system level - power-generating objects (PGO). Their specificity is related to the direct production of electricity and heat and ensure the qualitative aspect of the process.

In general, the definition of development risks in electricity propose the existence of potential threats, which can be realized in the electricity enterprise (with a high probability) and lead to a deterioration in its competitive position in the market and further development. Electricity development risks include the probability of reaching high BPA deterioration, irrational pricing of policies, inefficient investment decisions and high tax burdens.

\subsection{The definitions of electricity development risks}

In accordance with the characteristics of the power system elements at the PGC level, the following development risk groups apply [4-7]:

1. Financial risks - the probability of the appearance of unforeseen financial losses (profit or income reducing, capital losses, increasing of borrowed funds dependence, worsening of "goodwill" indicator) in situations of indeterminacy of the financial terms of company. In electricity branches, these types of risks are some of the most serious and difficult to manage. The specifics of these risks are: lack of experience of competitive electricity market participants, difficulty in the realization of the company's investment program and the large probability of insolvent consumers [8].

2. Technical and economic risks - this concerns the probability of losses arising from the adoption and implementation of non-rational management decisions with a significant deviation from the investment program of the PGC. This group, in the first instance, includes risks related to costs increasing as a result of technical wear of electricity equipment (according to PGC reports the volume of retiring generation capacity by 2020 may reach $75 \%$ [9]), and also to fuel cost increasing and the general rise of first production cost. In addition, this group can include the risks of having an irrational structure of power-generation capacity, which can lead to the competitive reduction of prices on the energy market. An additional feature is in the range of the regulatory-legal framework in relation to the establishment of tariffs for electricity and heat.

3. Project risks - the risks arising from the financing of electricity capital projects. As a rule this is due to the changing of initial conditions of the project's financing and also to additional costs in the form of institutional risks (increased tax payment, changing of currency exchange, etc.). 
A description of the developing risks group specific to $\mathrm{PGO}$ is presented below [4-6, 10]:

1. Ecological risks - the heat station during operation emits significant amounts of dangerous compounds that harm the biosphere. Furthermore, they have detrimental thermal effects on the environment and affect the topography.

2. Technological risks of the power-generation company include the processes for the quality adherence of services and the safety of heat and electricity, which are realized through the modes of PGO, as the main equipment.

3. Fuel supply risks - the irrational balance of fuel (gas, petroleum, coal, fuel and oil), the imbalance of fuel stocks in technical terms at the stations, as well as rising fuel prices.

\subsection{The structure of electricity development risks}

The risks ingredients of $\mathrm{PGO}$ and $\mathrm{PGC}$, which characterize their structure, are presented in Table 1.

Table 1: Decomposition of the development risks of power companies and their objects.

\begin{tabular}{|c|c|c|}
\hline № & $\begin{array}{l}\text { Group of development } \\
\text { risks }\end{array}$ & Types of development risks \\
\hline 1. & Finance risks & $\begin{array}{l}\text { 1.1. The slowdown of capital turnover } \\
\text { 1.2. Growth of outstanding debt } \\
\text { 1.3. Lower profit } \\
\text { 1.4. Growth in accounts payable } \\
\text { 1.5. The decrease in investment }\end{array}$ \\
\hline 2. & $\begin{array}{l}\text { Technical and } \\
\text { economic risks }\end{array}$ & $\begin{array}{l}\text { 2.1. Growing share of obsolete equipment in the total } \\
\text { amount of BPA } \\
\text { 2.2. Rising cost of fuel } \\
\text { 2.3. Increase in the cost of power } \\
\text { 2.4. Irrational tariff policy }\end{array}$ \\
\hline 3. & Project risks & $\begin{array}{l}\text { 3.1. Increase in the cost of the project } \\
\text { 3.2. Increasing the duration of the investment phase } \\
\text { of the project } \\
\text { 3.3. Institutional risks }\end{array}$ \\
\hline 4. & Ecological risks & $\begin{array}{l}\text { 4.1. Above normal greenhouse gases tons of nitrogen } \\
\text { oxides } \\
\begin{array}{l}\text { 4.2. Above normal thermal effects on the } \\
\text { environment }\end{array}\end{array}$ \\
\hline 5. & Technological risks & $\begin{array}{l}\text { 5.1. Violation of equipment reliability } \\
\text { 5.2. Violation of the regime of functioning } \\
\text { 5.3. Equipment failure, damage it } \\
\text { 5.4. Deviation of the frequency of the current } \\
\text { 5.5. Deviation of the voltage } \\
\text { 5.6. Of casualties and damage equipment }\end{array}$ \\
\hline 6. & Risks of fuel supply & $\begin{array}{l}\text { 6.1. The rising price of coal } \\
\text { 6.2. Deterioration in the quality of fuel } \\
6.3 \text {. Disruptions in the supply of fuel }\end{array}$ \\
\hline
\end{tabular}




\section{The method of investor attractiveness assessment}

The developed method of PGC investor attractiveness assessment process with specific development risks uses expert-analytical methods of qualitative analysis. This technique is used to justify the decision on the eligibility of the project's financing while minimizing the value of the subjective assessments of the risk analysis model based on the results of the judgments of highly professional experts. The steps of this method are represented in Fig. 1.

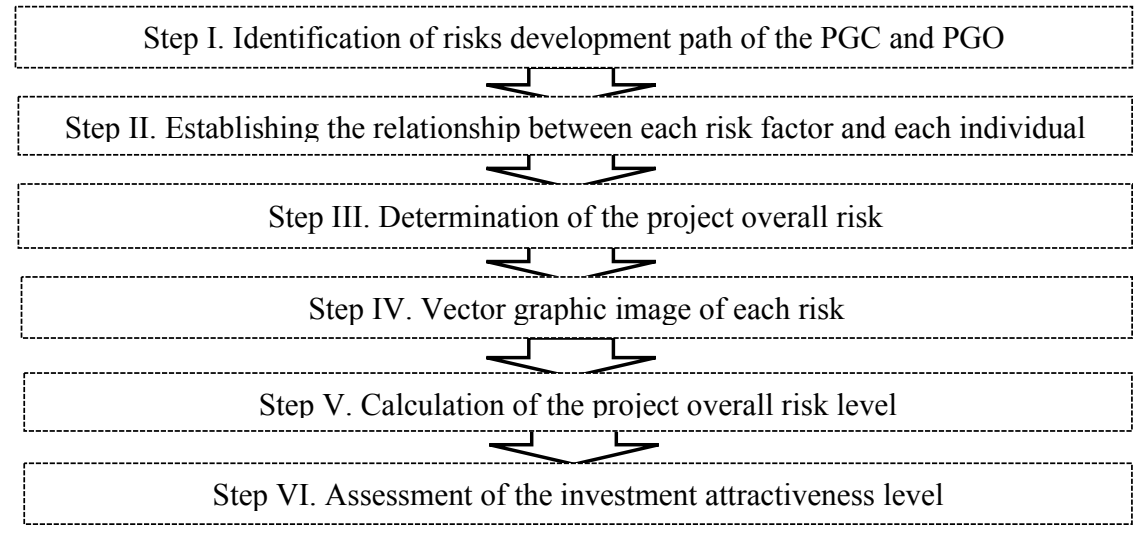

Figure 1: Steps scheme of PGC investor attractiveness assessment.

\subsection{The method indicators}

To assess the threat level and, thus, the costs of development risks in the project financing in the power-generating object, the impact of risks on private indicators must be considered (Table 2). This, in turn, allows us to assess the values, for which to depend upon, for the final financial results of the investment project. The methodological link between the types of development risks and the private figures significantly impacts these threats, the final amount of revenue and hence the profit of the company. For example, the implementation of technological risks will increase the costs associated with the repair of equipment, etc.

Also this can highlight the general indicators that describe the parameters of the investment project, such as the volume of attracted financing, the share of the company's own funds, a loan term, grace period, etc.

The evaluation of the development risk's impacting levels on the project, based on expert opinion, uses the scale below [11]:

Up to $15^{\circ}$ - low degree of influence;

$15^{\circ}-30^{\circ}$ - a moderate degree of influence;

$31^{\circ}-45^{\circ}$ - a significant degree of influence;

$46^{\circ}-60^{\circ}$ - a strong degree of influence;

$61^{\circ}-75^{\circ}$ - critically strong degree of influence;

$76^{\circ}-90^{\circ}-$ catastrophically strong degree of influence. 
Table 2: $\quad$ Private figures used in electricity development risks analysis.

\begin{tabular}{|l|c|c|}
\hline \multicolumn{1}{|c|}{ Private indicator } & Symbol & Rating formula \\
\hline $\begin{array}{c}\text { 1.Profitability of } \\
\text { project assets }\end{array}$ & $P_{1}$ & Project pre-tax profit/Project assets \\
\hline $\begin{array}{c}\text { 2.Profitability of } \\
\text { project sale }\end{array}$ & $P_{2}$ & Project profit/Project revenue \\
\hline 3.Tax liabilities & $P_{3}$ & Project profit tax value/Project revenue \\
\hline $\begin{array}{l}\text { 4.Project solvency } \\
\text { 5.Project liquidity }\end{array}$ & $P_{4}$ & $\begin{array}{c}\text { Current liabilities * Evaluation } \\
\text { period/Project revenue }\end{array}$ \\
\hline $\begin{array}{c}\text { 6.Projet autonomy } \\
\text { 7.Prosperity of own } \\
\text { funds }\end{array}$ & $P_{6}$ & $\begin{array}{c}\text { Equity capital/Capital invested to project } \\
\text { assets }\end{array}$ \\
\hline $\begin{array}{c}\text { 8.Absolute liquidity } \\
\text { 9.Average output per } \\
\text { worker }\end{array}$ & $P_{8}$ & $\begin{array}{c}\text { Own current assets/Current assets } \\
\text { furrent liabilities }\end{array}$ \\
\hline
\end{tabular}

\section{Practical assessments of the relationship between each risk factor and each individual indicator}

In this study, a survey was carried out in the form of a questionnaire survey of experts (heads of services and departments of JSC "TGC-9") to assess the cost of development risks for a given scale, the results of which are presented in Table 3 [12].

\section{Graphical analyses of development risks}

Using the results of the calculation shown in Table 3 it can be concluded that the structure of development risks at the PGC level is the following: 52\% - financial risks, $35 \%$ - technical and economic risks and $13 \%$ - project risks. At the PGO level: $54 \%$ - technological risks, $25 \%$ - risks of fuel supply and $21 \%$ - ecological risks.

The graphical assessment of the PGC and PGO's overall development risks are detailed in the images of Fig. 2 and Fig. 3, respectively.

When comparing the share of PGC and PGO development risks it is exposed that the share of company risks is $56 \%$ and the proportion of object risks is about $44 \%$. Thus the PGC development risks are more significant for making an investment decision. In addition to this, a comparison of the future share risks is needed to analyze the development risks cost for the assessment of the PGC investor attractiveness level. The level of influence of all the risks is given in Fig. 4. 


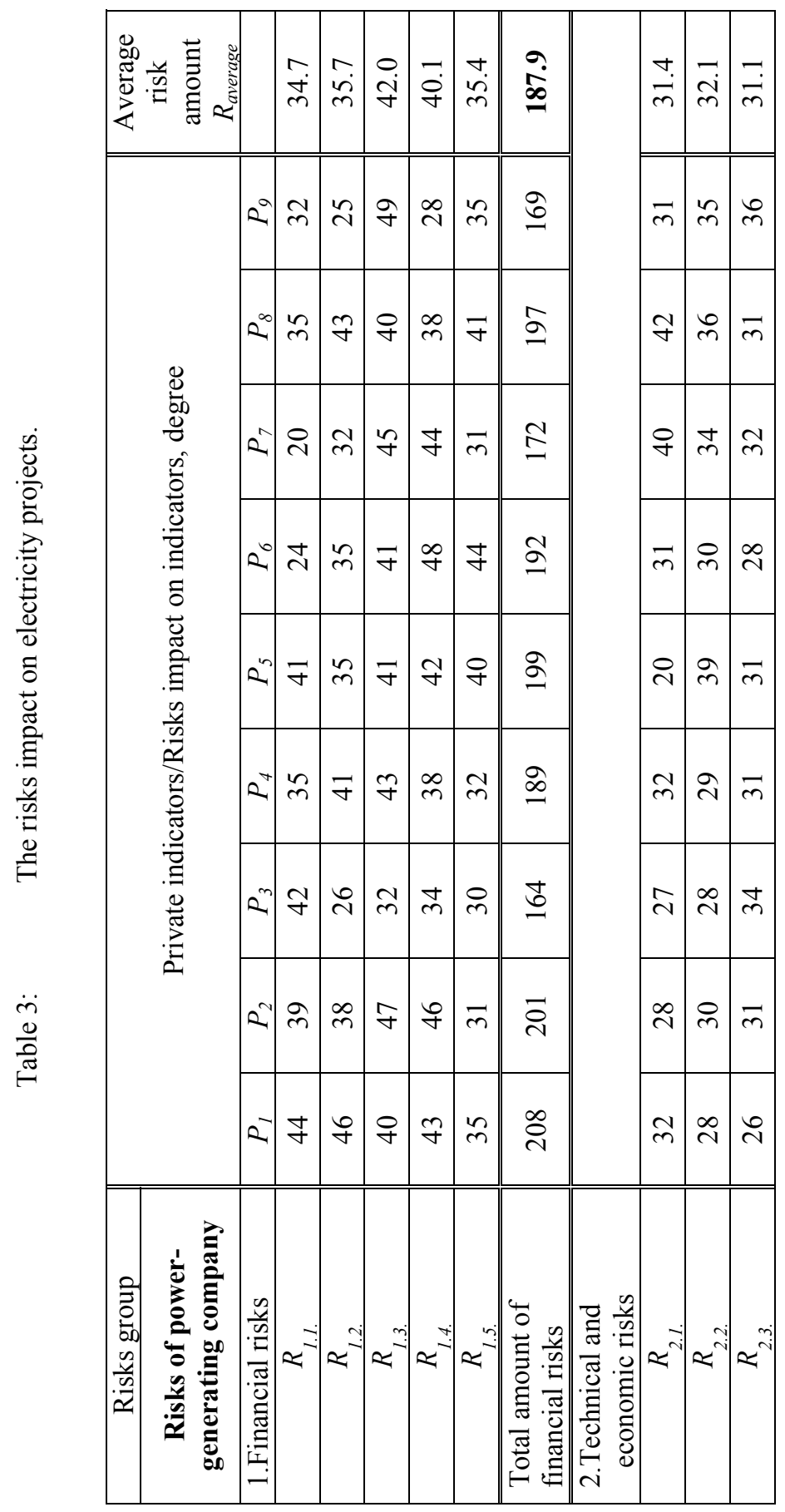




\begin{tabular}{|c|c|c|c|c|c|c|c|c|c|c|c|c|}
\hline $\begin{array}{l}0 \\
\stackrel{\sim}{ }\end{array}$ & 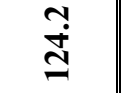 & & $\stackrel{n}{n}$ & $\begin{array}{l}\sigma \\
\end{array}$ & $\ddot{n}$ & ஒे & $\stackrel{\stackrel{\theta}{0}}{\stackrel{0}{0}}$ & & & $\begin{array}{l}0 \\
\dot{0} \\
m\end{array}$ & $\overrightarrow{\dot{0}}$ & $\ddot{8}$ \\
\hline ষ & $\stackrel{0}{\simeq}$ & & $\stackrel{\sim}{ }$ & $\approx$ & 0 & $n$ & త్రి & & & 9 & $\vec{\sim}$ & $\stackrel{\ominus}{\forall}$ \\
\hline$\stackrel{ }{\sim}$ & ปิ & & $\stackrel{ }{1}$ & $\Xi$ & 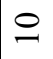 & ঙ & లి & & & $\bar{m}$ & $\bar{m}$ & 즈 \\
\hline N & $\stackrel{\infty}{\sim}$ & & $ㅇ$ & $\stackrel{n}{\sim}$ & 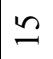 & 유 & రి & & & $m$ & $\approx$ & $\infty$ \\
\hline$\underline{-}$ & $\stackrel{\infty}{\circ}$ & & $\stackrel{\circ}{\sim}$ & $\underline{-}$ & $\infty$ & ஜ & రి & & & $\stackrel{n}{+}$ & 앙 & 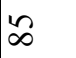 \\
\hline$\approx$ & ป & & 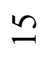 & $n$ & $a$ & ले & हి & & & ฉે & $\approx$ & in \\
\hline $\bar{m}$ & 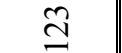 & & 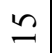 & 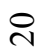 & 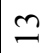 & $\stackrel{\infty}{\sim}$ & రి & & & $\tilde{m}$ & m & 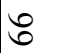 \\
\hline$\hat{n}$ & ปి & & $\simeq$ & $\ddot{\sim}$ & 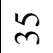 & 웅 & రి & & & $\stackrel{\infty}{\sim}$ & নे & in \\
\hline 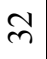 & $\vec{\beth}$ & & $\simeq$ & 二 & $\simeq$ & $\underset{\sim}{\infty}$ & ஜి & & & $\vec{m}$ & $m$ & オ \\
\hline શે & 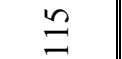 & & \pm & $n$ & $\infty$ & $\hat{m}$ & రిల్ల & & & $\widetilde{N}$ & $\approx$ & $\stackrel{n}{\forall}$ \\
\hline$x_{-}^{+}$ & 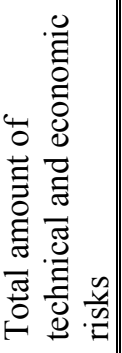 & 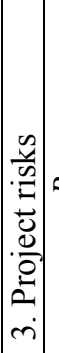 & $\approx=$ & $\Sigma^{m}$ & $\alpha^{m}$ & 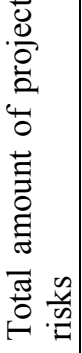 & 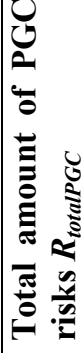 & 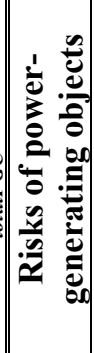 & 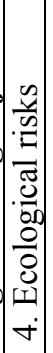 & $\approx$ & $\approx$ & 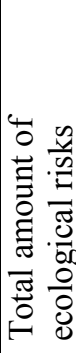 \\
\hline
\end{tabular}




\begin{tabular}{|c|c|c|c|c|c|c|c|c|c|c|c|c|c|}
\hline & $\begin{array}{l}ナ \\
\stackrel{\sim}{\sim}\end{array}$ & $\begin{array}{l}o \\
\stackrel{\sim}{\sim}\end{array}$ & $\begin{array}{l}\infty \\
\stackrel{0}{0} \\
\sim\end{array}$ & $\underset{d}{\stackrel{d}{d}}$ & $\frac{m}{\sim}$ & $\tilde{n}$ & 守 & & $\underset{\sim}{\stackrel{\Xi}{d}}$ & $\begin{array}{l}\infty \\
\dot{d}\end{array}$ & $\tilde{\dot{d}}$ & $\ddot{8}$ & $\stackrel{m}{\stackrel{9}{N}}$ \\
\hline & $\underset{l}{0}$ & $\beth$ & $\vec{\sim}$ & Әे & $\stackrel{\sim}{\sim}$ & $\because$ & $\stackrel{\infty}{=}$ & & $\beth$ & 9 & $\vec{\sim}$ & $\hat{n}$ & $\frac{n}{N}$ \\
\hline & ปे & $\widehat{\sim}$ & $\widehat{\sim}$ & 오 & $\vec{\sim}$ & m & $\begin{array}{l}\infty \\
n \\
n\end{array}$ & & حे & 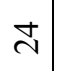 & 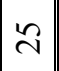 & $\stackrel{\infty}{\sim}$ & $\stackrel{\infty}{\stackrel{一}{2}}$ \\
\hline & $\approx$ & શે & ภે & શิ & $\infty$ & $m$ & 8 & & 9 & $\widehat{\sim}$ & 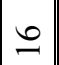 & ชิ & ริ \\
\hline & $\vec{\sim}$ & $\approx$ & $\approx$ & $\vec{\sim}$ & $\bar{v}$ & $\stackrel{\infty}{\sim}$ & 亓 & & $\vec{\sim}$ & $\widetilde{N}$ & $a$ & ชื & $\underset{\sim}{\infty}$ \\
\hline & 그 & $\infty$ & $\approx$ & $\stackrel{\bullet}{\sim}$ & ป & $\stackrel{\searrow}{\searrow}$ & $\stackrel{\Xi}{\sim}$ & & $\tilde{\sim}$ & $\stackrel{\infty}{\sim}$ & $\ddot{\sim}$ & $\stackrel{⿱ 亠 乂}{\sim}$ & స్రి \\
\hline & $m$ & $\widetilde{N}$ & へे & N & $\vec{\sim}$ & ํ. & $\tilde{n}$ & & $\approx$ & خे & $\infty$ & $\mathbb{N}$ & స్ \\
\hline & 요 & $\bar{m}$ & さ & $\vec{\sim}$ & 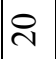 & 오 & $\stackrel{\circ}{ \pm}$ & & Әे & $\vec{\sim}$ & $\vec{\sim}$ & $\nabla$ & $\underset{N}{\mathbb{N}}$ \\
\hline & 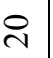 & ָ̃ & নे & $\stackrel{\Xi}{\sim}$ & $\bar{m}$ & $\nabla$ & 6 & & $\stackrel{\circ}{m}$ & $\stackrel{\searrow}{\sim}$ & 2 & $\Re$ & ষ্ল \\
\hline & ले & $\stackrel{\circ}{\circ}$ & N & 沉 & $\infty$ & $\approx$ & ô & & $\approx$ & خे & $\stackrel{\searrow}{\sim}$ & $\stackrel{\infty}{\sim}$ & ๙ૂ \\
\hline 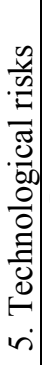 & $\approx$ & $\approx^{2}$ & $\approx \underbrace{\infty}$ & $\alpha^{\prime \prime}$ & $\approx^{2 n}$ & 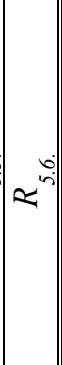 & 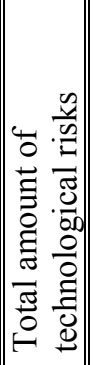 & 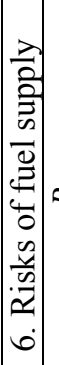 & $2^{-\overrightarrow{0}}$ & $\approx^{-8}$ & $\approx^{2}$ & 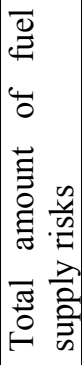 & 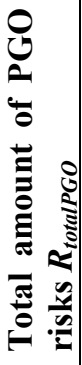 \\
\hline
\end{tabular}




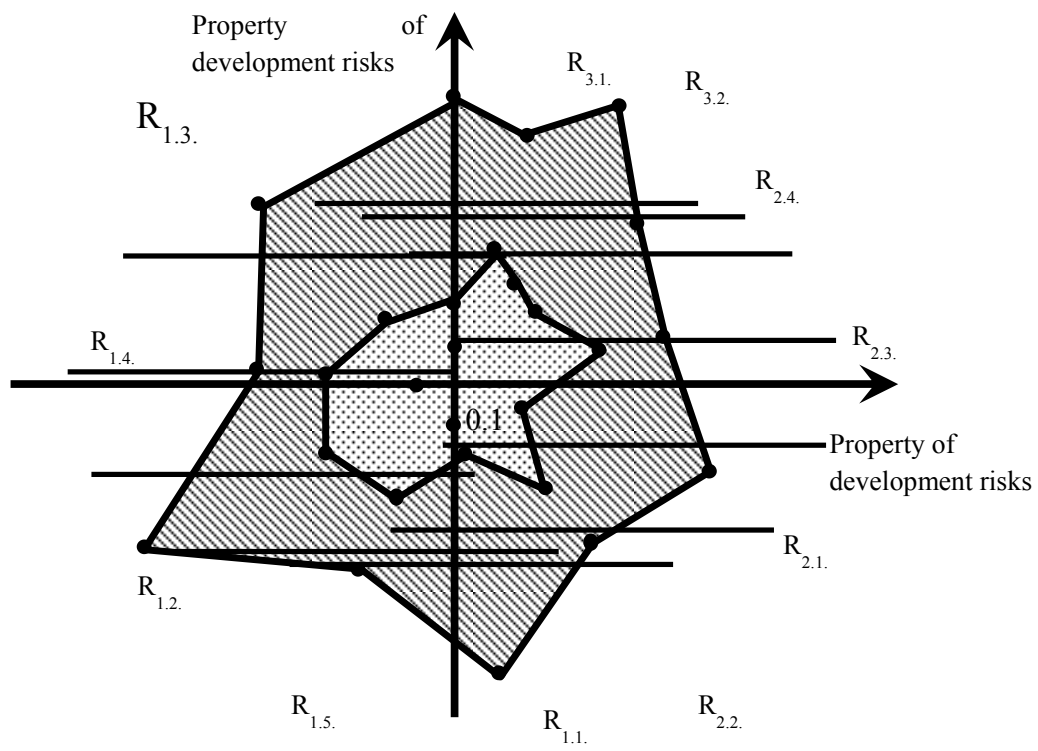

Figure 2: $\quad$ Graphical representation of the PGC total development risks.

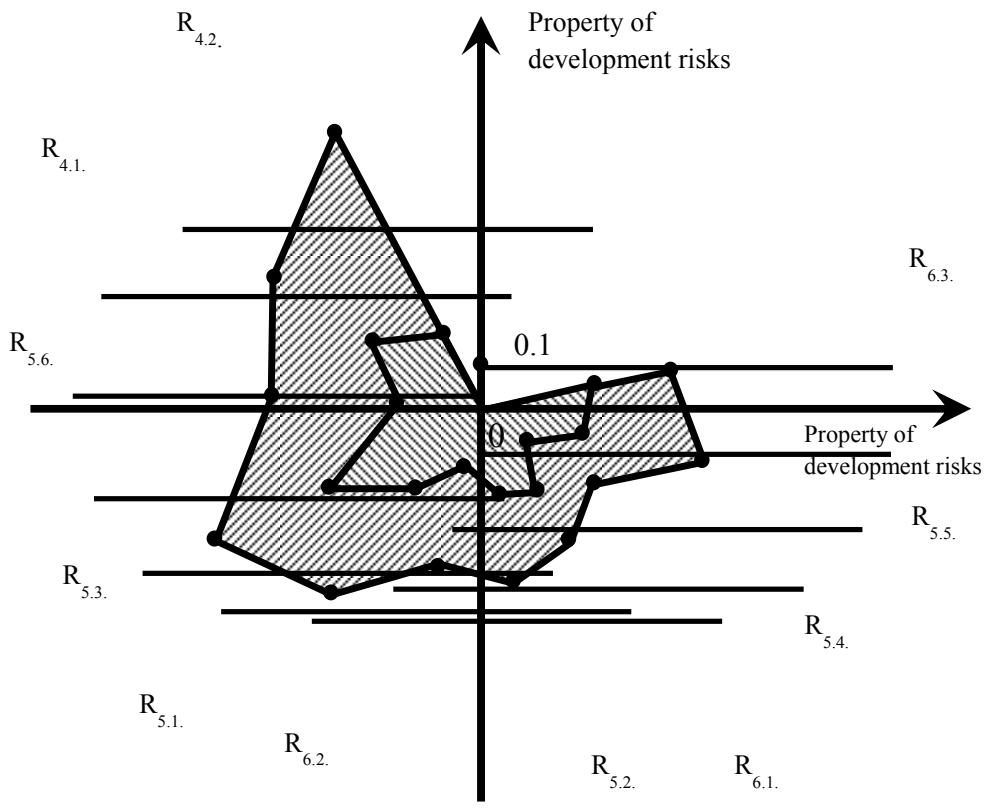

Figure 3: $\quad$ Graphical representation of the PGO total development risks. 


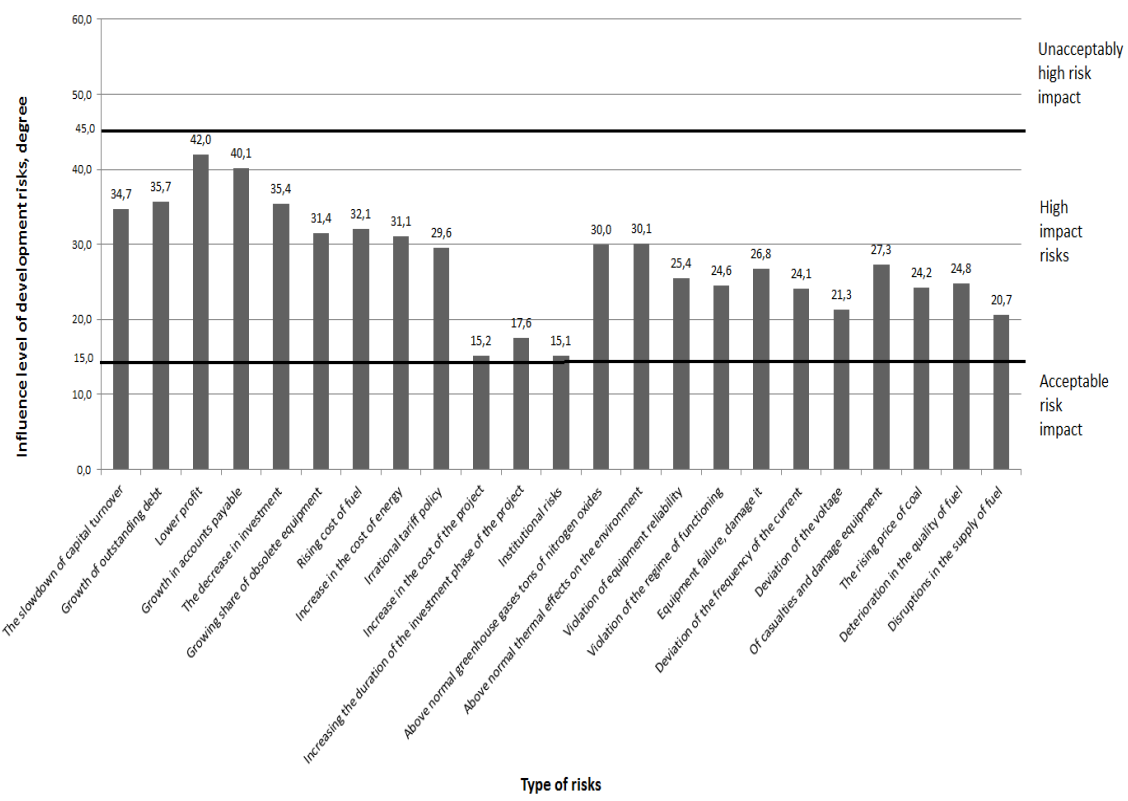

Figure 4: Influence level of every development risk on structural unit.

According to the developed methodology the PGC investor attractiveness assessment is based on determining the level of development risks impact on the basis of the following scale:

Up to $15^{\circ}$ - acceptable risk impact;

$15^{\circ}-45^{\circ}$ - high risk impact;

Over $45^{\circ}$ - unacceptably risk impact.

In this case, Fig. 4 shows that none of the development risks rise above the $45^{\circ}$ limit (unacceptably risk impact), three risks are in the $15^{\circ}$ limit (acceptable risk impact) and only two of the 23 development risks are over the $40^{\circ}$ level. The average risk value for the project is $27.8^{\circ}$. All this indicates a high level of PGC investor attractiveness.

\section{Calculation of overall project risk}

The next step of the PGC investor attractiveness assessment is the determining of the actual magnitude of total development risk, the calculation of which is as follows (1):

$$
S_{\mathrm{int}}=\frac{\sum\left[R_{i} * R_{i+1} * \sin \left\{\left(\sum \alpha_{R_{n}}\left(P_{i}\right)+\sum \alpha_{R_{n}}\left(U_{j}\right)\right) /(m+k)\right\}\right]}{2}
$$


where:

$S_{\text {int }}$ - index of aggregate risk value;

$R_{i}=$ side $a$;

$R_{i+1}=$ side $b$.

$$
\left(\sum \alpha_{R_{n}}\left(P_{i}\right)+\sum \alpha_{R_{n}}\left(U_{j}\right)\right) /(m+k)=\operatorname{angle} \alpha
$$

where:

$\alpha_{R n}\left(P_{i}\right)$ - the value of the expert assessment of $n$-th factor impact in $i$-th component of the project financial and economic sustainability;

$\alpha_{R n}\left(U_{j}\right)$ - the value of the expert assessment of $n$-th factor impact in $j$-th component of the project total result;

$k$ - the quantity of estimate indicates of the project final result;

$m$ - the quantity of estimate indicates of the project financial and economic sustainability.

The calculations show that if the average amount of risk realization is 0.5 (maximum of this one is 0.7 , the minimum is 0.3 ) then the total development risk value will be: for PGC -0.8599 and for PGO -0.6828 . The final amount of development risk $\left(S_{i n t}\right)$ for PGC and PGO is 1.5427 . For the final decision on financing for this investment project, it is necessary to compare the date with the average sector index, which is approximately 2.200 [5].

Thus the total risk figure of the company and the object is below the industry average in absolute values by 0.6573 and relative to $29.88 \%$. This indicates the high level of attractiveness for this energy business investment.

\section{Conclusions}

In general, the graphic-analytical approach of the PGC investor attractiveness evaluation that is presented in this paper takes the development risks value of electricity, in the first place, and includes components such as: the assessment of every identified risks value in accordance with the scale, thus, the average amount and also the total project risk amount compared with the average industry value.

The calculations show that the PGC share has 1.3 times more risks than the PGO share. This is primarily due to the fact the PGC bear a great responsibility and are responsible for the efficient work (in the production and financial aspects) and the uninterrupted supply of fuel to PGO and qualitative functioning of the equipment. That is why the structure of all the risks for the share of PGC risks accounts for a large proportion (Fig. 4) - their average value is greater than $30^{\circ}$. The development risks inherent of the PGO have an average size of $25^{\circ}$.

In the study of the specific risks, the most dangerous risks for the company such as lower profit and growth in accounts payable, were identified, also 
including the least dangerous - institutional risks and increase in the cost of the project.

The methodical approach that is presented in this paper allows us to estimate the level of PGC investor attractiveness for the future decision about the project financing for the modernization, expansion, renovation and creation of a new PGO. However, with the passage of time the situation on the energy market and in PGC may change, therefore, this process of assessment should be performed regularly and the amplification of adverse factors implements measures to neutralize them.

\section{References}

[1] Marder, L.I., Scientific and methodological principles, methods and practices of development indicators in conjunction with the electric fuel and energy complex and subject to regional factors, Ural State Technical University: Ekaterinburg, pp. 20-21, 1993.

[2] Default and Recovery Rates for Project Finance Bank Loans, 1983-2008; Moodys Agency, www.moodys.com.

[3] Corporate Default and Recovery Rates, 1920-2009; Moodys Agency, www.moodys.com.

[4] Gitelman, L.D., Ratnikov, B.E., Energy business, Delo: Moscow, pp. 100-110, 2006.

[5] Domnikov, A.Yu. Competitive development of cogeneration systems of energy, Ural State Technical University: Yekaterinburg, pp. 54-55, 2008.

[6] Domnikov, A.Yu. Managing the development of electric power industry, Institute of Economics, Ural Branch of RAS: Ekaterinburg, pp. 60-61, 2006.

[7] Belikov, T.A. Minefields of project financing, Harvard Business Review: Moscow, pp. 25-27, 2009.

[8] Shevchuk, A.Y. Particularly financial risks and risk - management in the power. Economics and Management: theoretical and practical aspects, 1, pp. 12-13, 2011.

[9] Russian statistics of energy business in 2013; Russia statistic Agency, www.lenta.ru.

[10] Nepp, A.N. Predicting the risk of borrowers in the commercial banking and credit. Issues of Risk Analysis, 1(9), 2012.

[11] Astarkina, N.R. Financial - economic assessment methodology of the overall risk of project finance for small business. Management of economic systems. A series of finance and credit, 8, pp.15-16, 2011.

[12] Chebotareva, G.S. Personal communication, 20 January 2013, Assistant of Banking chair, Ural Federal University, Ekaterinburg, Russia. 